\title{
Cells transformed by murine herpesvirus 68 (MHV-68) release compounds with transforming and transformed phenotype suppressing activity resembling growth factors
}

\author{
M. ŠUPOLÍKOVÁ ${ }^{1}$, A. VOJS STAŇOVÁ2, M. KÚDELOVÁ ${ }^{3}$ J. MARÁK², V. ZELNÍK³, F. GOLAIS ${ }^{1}$
}

\begin{abstract}
${ }^{1}$ Comenius University, Faculty of Natural Sciences, Department of Microbiology and Virology, Mlynská dolina B2, 84215 Bratislava, Slovak Republic; ${ }^{2}$ Comenius University, Faculty of Natural Sciences, Department of Analytical Chemistry, Bratislava, Slovak Republic; ${ }^{3}$ Institute of Virology, Department of Molecular Pathogenesis of Viruses, Slovak Academy of Sciences, Bratislava, Slovak Republic
\end{abstract}

\begin{abstract}
Summary. - In this study, we investigated the medium of three cell lines transformed with murine herpesvirus 68 (MHV-68) in vitro and in vivo, 68/HDF, 68/NIH3T3, and S11E, for the presence of compounds resembling growth factors of some herpesviruses which have displayed transforming and transformed phenotype suppressing activity in normal and tumor cells. When any of spent medium was added to cell culture we observed the onset of transformed phenotype in baby hamster kidney cells (BHK-21) cells and transformed phenotype suppressing activity in tumor human epithelial cells (HeLa). In media tested, we have identified the presence of putative growth factor related to MHV-68 (MHGF-68). Its bivalent properties have been blocked entirely by antisera against MHV-68 and two monoclonal antibodies against glycoprotein B (gB) of MHV-68 suggesting viral origin of MHGF-68. The results of initial efforts to separate MHGF-68 on FPLC Sephadex G15 column in the absence of salts revealed the loss of its transforming activity but transformed phenotype suppressing activity retained. On the other hand, the use of methanol-water mobile phase on RP-HPLC C18 column allowed separation of MHGF-68 to two compounds. Both separated fractions, had only the transforming activity to normal cells. Further experiments exploring the nature and the structure of hitherto unknown MHGF-68 are now in the progress to characterize its molecular and biological properties.
\end{abstract}

Keywords: murine herpesvirus; MHV-68 transformed cell line; putative growth factor MHGF-68; separation techniques

In nineties of the $20^{\text {th }}$ century, a new class of compounds encoded by some herpesviruses (pseudorabies and herpes simplex virus (HSV) 2) resembling growth factors has been found in medium of mammalian cells cultured under conditions non-permissive for virus replication. These compounds designed as virus related growth factors (PRGF and HSGF) displayed unique effects on cell culture either infected or transformed with corresponding virus (Golais

E-mail: supolikova@fns.uniba.sk; phone: +421-2-60296631. Abbreviations: $\mathrm{gB}=$ glycoprotein $\mathrm{B} ; \mathrm{MHV}=$ murine herpesvirus 68; MHGF-68 = MHV-68 related growth factor; 68/HDF = human dermal fibroblasts transformed by MHV-68; 68/NIH3T3 = mouse embryonal cells transformed by MHV-68 et al., 1990, 1992a). Non-transformed cells cultivated in the presence of these factors acquired the transformed phenotype ("criss-cross" pattern of growth), while the phenotype of transformed cells became changed towards the normal ones (Gašperík et al., 1994; Konvalina et al., 2002). Both activities could be neutralized by antisera to corresponding virus and also by some monoclonal antibodies directed against viral glycoprotein B (gB) (Golais et al., 1992b). Furthermore, our previous studies on HSV-1 strains that differ in $g B$ sequence (e.g in syn ${ }^{3}$ locus) revealed, that $g B$ might be involved at least in the function of these factors (Golais et al., 1992b; Rajčáni et al., 1996).

Recently, two cell lines transformed by MHV-68 derived from human dermal fibroblasts and mouse embryonal cells were prepared, in this paper designed as 68/HDF and 68/ 
(a)

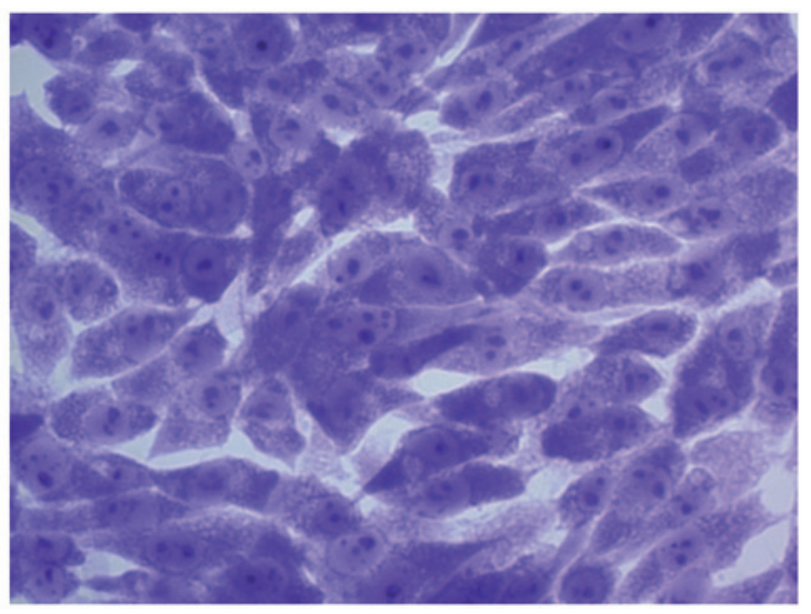

(c)

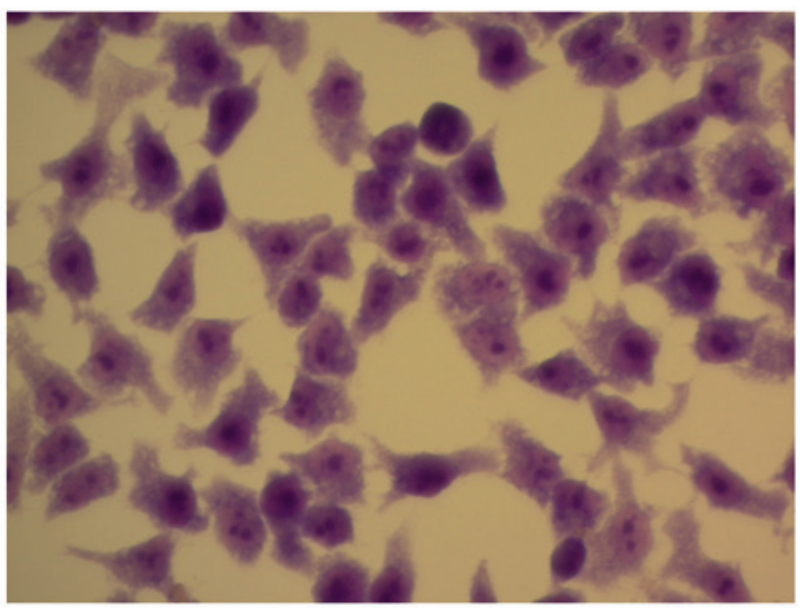

(b)

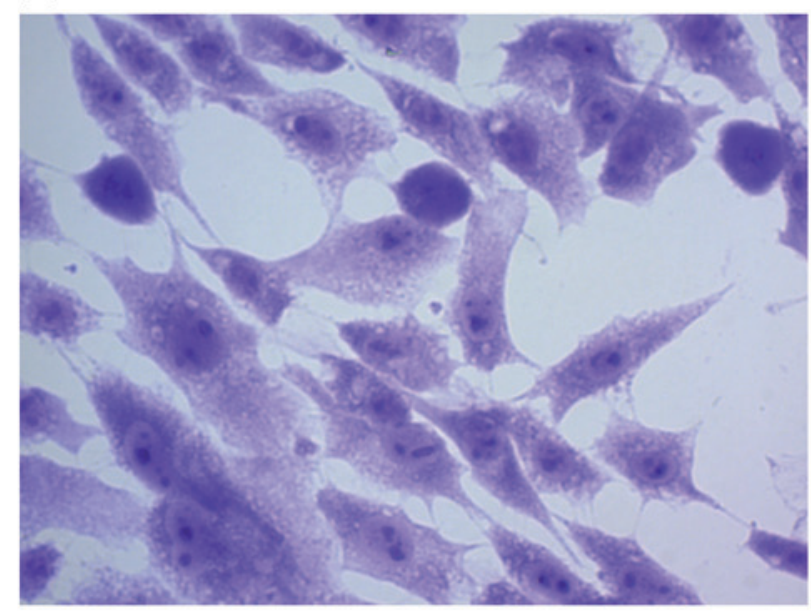

(d)

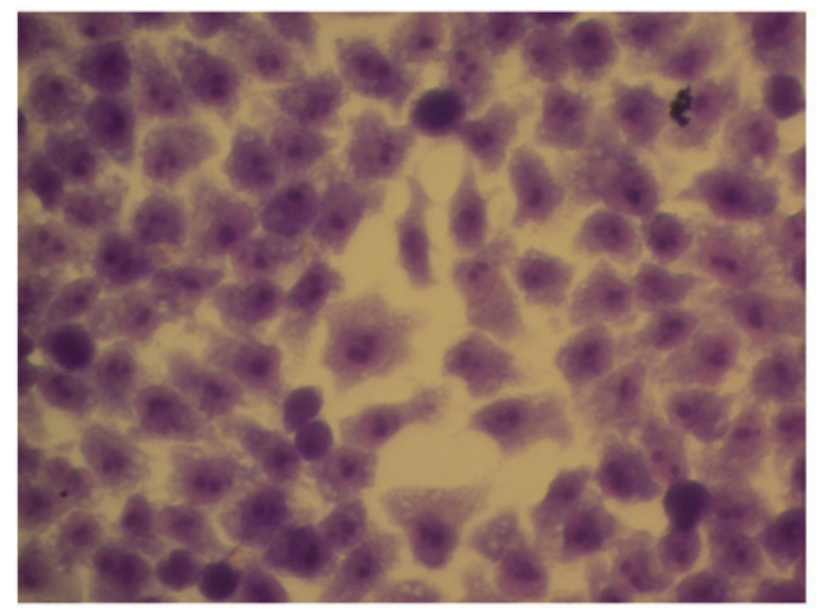

Fig. 1

The effect of putative MHGF-68 (present in the medium of 68/NIH3T3 cells) on cultured BHK-21 (a) and HeLa cells (c) observed by comparing to untreated BHK-21 (b) and HeLa (d) cells under light microscopy

NIH3T3. In both, the presence of viral antigen and genome but the absence of infectious virus release have been found (Mrázová et al., 2015). In this study, we demonstrated the presence of putative MHV-68 related growth factor (MHGF-68) in the medium of both MHV-68 transformed cell lines following its biological activities that have arisen after its addition to cultivation medium of normal baby hamster kidney cells (BHK-21) and transformed human epithelial cells (HeLa). We have found that BHK-21 cells cultivated with medium of MHV-68-transformed cells, either with 68/HDF or 68/ NIH3T3 cells (Fig. 1a), acquired changed morphology resembling that observed with similar herpesvirus-related growth factors (Dušinská et al., 1994; Konvalina et al., 2002). On the other hand, HeLa cells cultivated with the same media displayed the phenotype of non-transformed cells (Fig. 1c). We have found that compounds present in the media of cell lines transformed with MHV-68 in vitro exhibited similar bivalent properties described earlier for growth factors of herpesviruses. When these media were incubated with rabbit antiserum against $\mathrm{MHV}-68\left(30 \mathrm{~min}\right.$ at $\left.37^{\circ} \mathrm{C}\right)$ before its testing on BHK-21 or HeLa cell cultures, both activities disappeared. This finding indicated that the observed activities are related to compounds in the medium to be of viral origin. In following experiments we treated these media with several monoclonal antibodies against $\mathrm{gB}$ of MHV-68 (Gillet et al., 2006; Glauser et al., 2011). As summarized in Table 1, two out of seven monoclonal antibodies tested, MG-1A12 (recognizing conformational epitope and requir- 
Table 1. Neutralization of biological activity of MHGF-68 (present in the medium of 68/HDF and 68/NIH3T3 cells) with monoclonal antibodies against glycoprotein B of MHV-68

Monoclonal antibody Characteristics of monoclonal antibody

Neutralization

\begin{tabular}{ll}
\hline MG-4D11 & recognizes C-terminal half of gB $(55 \mathrm{~K})$, works on western blots \\
\hline MG-1C12 & recognizes conformational gB epitope requiring the whole protein \\
\hline BN-2B11 & recognizes conformational epitope in N-terminal half of gB \\
\hline MG-1A12 & recognizes conformational epitope requiring the whole protein \\
\hline SC-9E8 & recognizes conformational epitope in N-terminal half of gB, neutralization \\
\hline MG-2H4-D9 & $\begin{array}{l}\text { IgM, recognizes N-terminus of gB, works on western blot, sensitive to cell type-specific O-glyco- } \\
\text { sylation }\end{array}$ \\
\hline BN-1A7 & recognizes conformational epitope in N-terminal half of gB \\
\hline
\end{tabular}

ing the whole protein) and neutralizing antibody SC-9E8, which recognizes conformational epitope in $\mathrm{N}$-terminal half of $\mathrm{gB}$, were capable of preventing both transforming as well as transformed phenotype suppressing activity of MHGF68. In the media of both MHV-68 transformed cell lines we have found similar disappearance of both activities as with the rabbit antiserum confirming the presence of putative growth factor MHGF-68.

To characterize the properties of MHGF-68, aliquot volumes $(0.5 \mathrm{ml})$ of each media of both MHV-68 transformed cell lines were at first lyophilized and then resuspended in redistilled water $(100 \mu \mathrm{l})$. These samples were separated by RP-HPLC on C18 column using methanol-water mobile phase to obtain fractions of purified MHGF-68. Consequently, the latter samples were tested in BHK-21 and HeLa cells observing the onset of transformed phenotype and transformed phenotype suppressing activity. By separation on RP-HPLC C18 column we identified two components, $\mathrm{MHGF}_{\mathrm{A}}$ and $\mathrm{MHGF}_{\mathrm{B}}$, after elution of UV inactive $(220 \mathrm{~nm})$ absorbing material, which both displayed only the transforming activity to normal cells. As shown in Fig. 2, even $10^{10}$ times diluted MHGF-68 (fractions 8 and 9 of $\mathrm{MHGF}_{\mathrm{A}}$ and fractions 17 and 18 of $\mathrm{MHGF}_{\mathrm{B})}$ caused the onset of transformed phenotype of BHK-21 cells.

Better separation of MHGF-68 obtained from medium of both cell lines was achieved by FPLC on Sephadex G15 column (data not shown). An interesting fact observed was that the choice of mobile phase used determinates MHGF-68 activity retention. While phosphate buffered solution (PBS) ( $\mathrm{pH}$ 7.2) retained both activities of MHGF-68 (Fig. 3a) (the highest in the fraction 4 ), the use of redistilled water caused

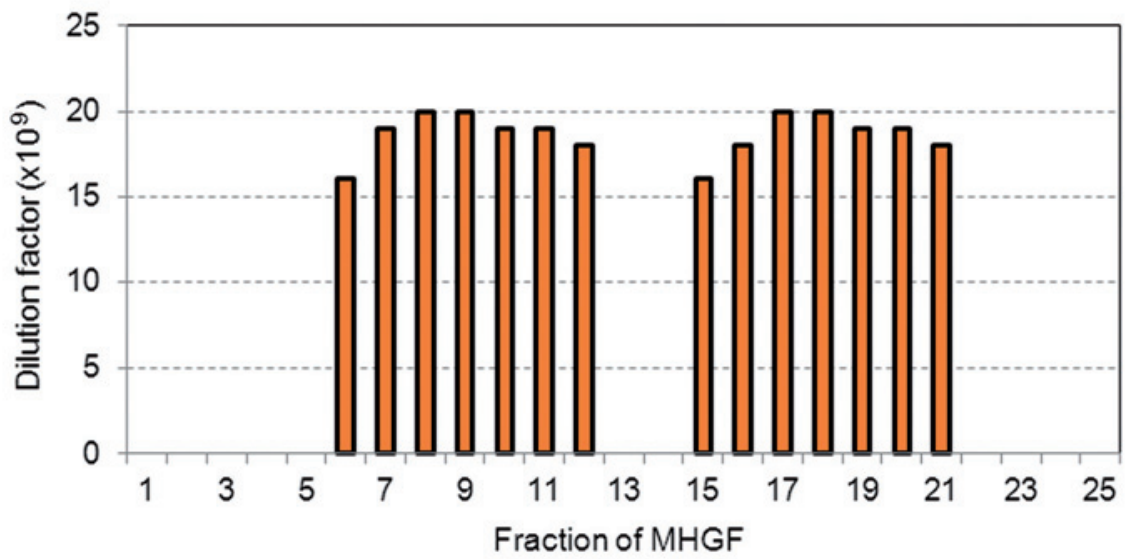

Fig. 2

Determination of MHGF-68 transforming activity to BHK-21 cells by limiting dilution of medium obtained from cultivation of 68 /NIH3T3 cells

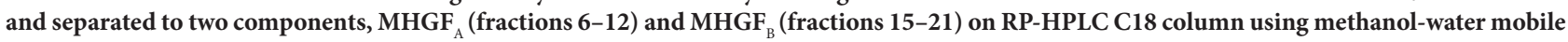
phase 


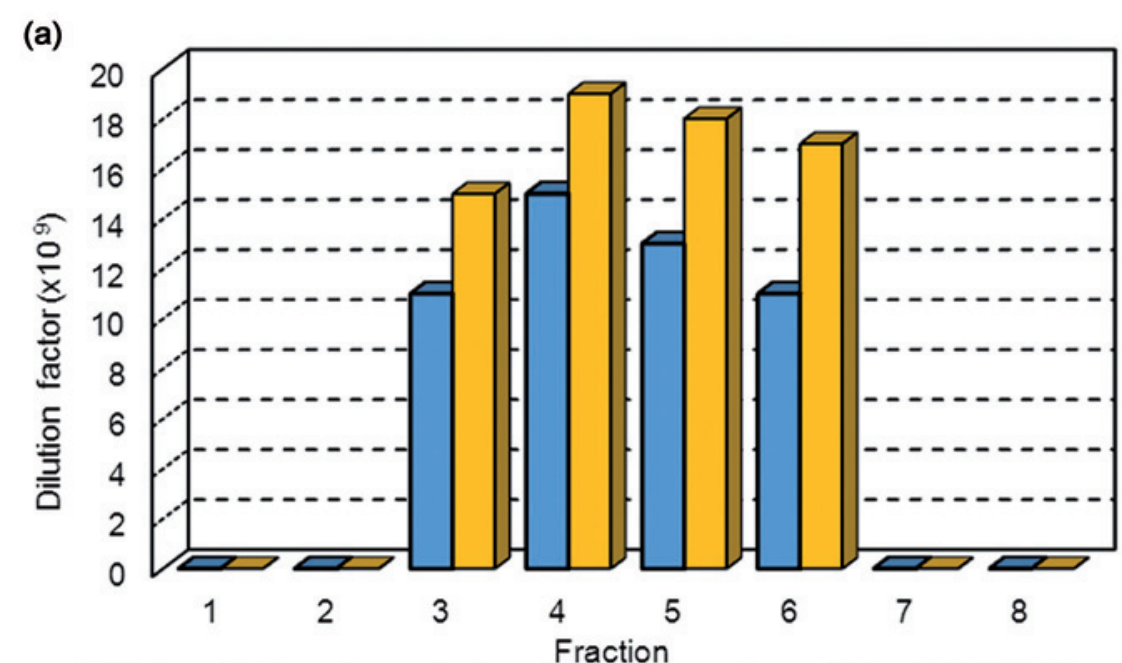

UheLa cells, transformed phenotype suppressing activity of MHGF-68

$\square$ BHK-21 cells, transforming activity of MHGF-68

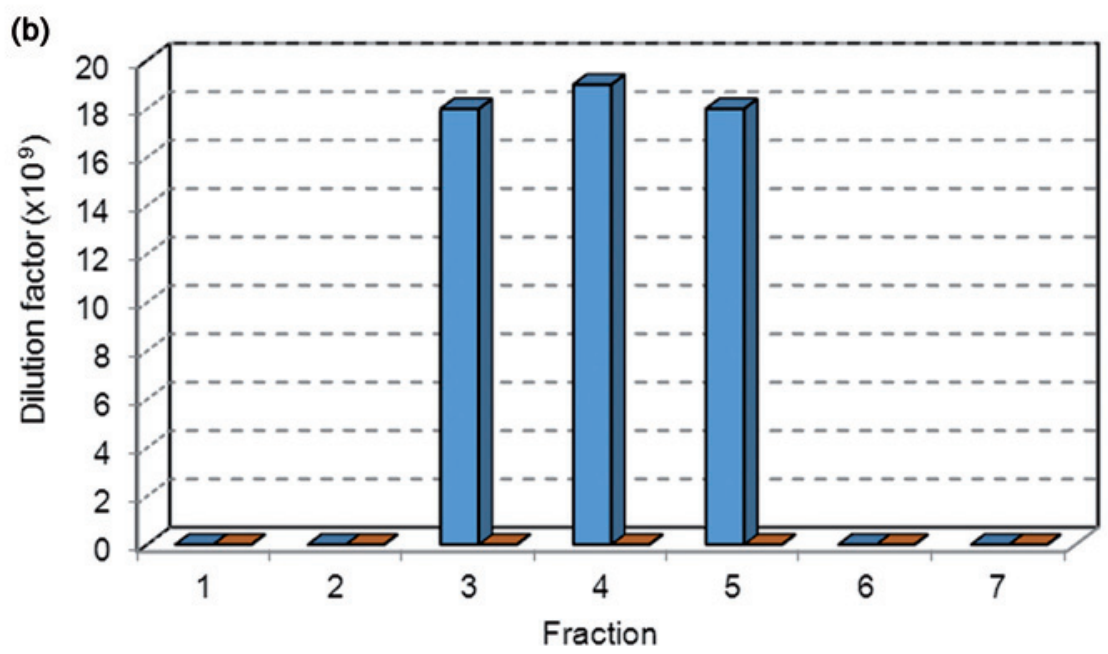

口HeLa cells, transformed phenotype suppressing activity of MHGF-68

口BHK-21 cells, transforming activity of MHGF-68

Fig. 3

Determination of MHGF-68 transformed phenotype suppressing activity to HeLa cells by limiting dilution of medium obtained from cultivation of 68/NIH3T3 cells and separated on FPLC column Sephadex G15 using phosphate buffered solution (a) and redistilled water (b)

the loss of transforming activity of MHGF-68 while suppressing transformed phenotype activity in HeLa cells was retained (Fig. 3b). The latter activity of MHGF-68 (fraction 4) seems to be even better than of any MHGF-68 fraction eluted with PBS. Based on results obtained from both types of chromatography, we assume that the absence of salts or presence of organic solvents might influence the structure important for biological properties of this newly found growth factor.
In the following experiments we compared the results obtained for MHGF-68 present in medium of in vitro transformed cells with that of tumor B cell line S11E, derived from an MHV-68 infected mouse suffering from lymphoproliferative disease. The cells of S11E line contain MHV-68 genome in both linear and episomal form and spontaneously release infectious virus (Usherwood et al., 1996). When we cultivated BHK-21 or HeLa cells with the medium of S11E cells we observed transforming or trans- 
formation suppressing activities in relevant cell culture identical with those observed for MHGF-68 described above (data not shown). Further experiments have shown that both activities present in the medium of S11E cells could be neutralized with antiserum against MHV-68 as well as with the same monoclonal antibodies (MG-1A12 and SC-9E8) described above. Thus, in the medium of S11E cells we very likely identified the same compounds, MHGF-68, found in the media of cell lines transformed by MHV-68 in vitro. The evaluation of its biological properties after separation on the C18 or Sephadex G15 column demonstrated similar biological activities described for MHGF-68 present in the cultivation medium of $68 / \mathrm{HDF}$ and 68/NIH3T3 cells (data not shown).

Finally, we identified MHGF-68, a growth factor related to MHV-68, in the medium of in vitro and in vivo transformed with MHV-68 cell lines, 68/HDF, 68/NIH3T3, and S11E. MHGF-68 displayed transforming and transformed phenotype suppressing activity in BHK-21 and HeLa cell culture resembling growth factors of some herpesviruses. We identified MHGF- 68 to be vacant of transforming activity in the absence of salts (e.g. by treatment with redistilled water during the separation on the column), which might help to find its potential application in the treatment of tumors in the future. The attempts are now in the progress aimed at uncovering the nature, the structure as well as molecular and other biological properties of MHGF-68, hitherto unknown compounds related to MHV-68.

Acknowledgements. The authors would like to thank Dr. P. G. Stevenson, University of Cambridge, Department of Pathology, Division of Virology, for providing monoclonal antibodies, prof. J. P. Stewart, University of Liverpool, for providing S11 cell lines, and Dr. I. Režuchová, Department of Pathogenesis of Viruses, Institute of Virology, Slovak Academy of Sciences, for providing the rabbit antiserum. This work was supported by the grants from the Scientific Grant Agency of Slovak Republic VEGA No. 1/0262/13, Slovak Research and Development Agency No. APVV-0621-12 and Research and Development Operational Programme funded by the ERDF Grant No. ITMS 26240220086.

\section{References}

Dušinská M, Leško J, Golais F, Slameňová D (1994): Morphological transformation of Syrian hamster embryo cells by Pseudorabies virus related growth factor. Cancer Lett. 79, 125-129. http://dx.doi.org/10.1016/0304-3835(94)90250-X

Gašperík J, Leško J, Csabayová M, Golais F (1994): Pseudorabies virus growth factor can be resolved into two active components. Acta Virol. 38, 117-120.

Gillet L, Gill MB, Colaco S, Smith CM, Stevenson PG (2006): Murine gammaherpesvirus- 68 glycoprotein $\mathrm{B}$ presents a difficult neutralization target to monoclonal antibodies derived from infected mice. J. Gen. Virol. 87, 3515-3527.

Glauser, DL, Kratz AS, Gillet L, Stevenson PG (2011): A mechanistic basis for potent, glycoprotein B-directed gammaherpesvirus neutralization. J. Gen. Virol. 92, 2020-2033.

Golais F, Leško J, Hillerová A, Sabó A, Kolcunová A (1990): A putative virus-encoded growth factor in a crude extract of pseudorabies virus infected and transformed cells. Biol. Zent. bl. 109, 481-487.

Golais F, Csabayová M, Leško J, Bystrická M, Sabó A (1992a): Herpes simplex virus type 2 and pseudorabies virus associated growth factors and their role in the latency in vitro. Acta Virol. 36, 505-515.

Golais F, Koštál M, Csabayová M, Leško J (1992b): The glycoprotein $B$ gene and its syn 3 locus of herpes simplex virus type 1 are involved in the synthesis of virus-associated growth factor (HSGF-1). Acta Virol. 36, 516-523.

Konvalina I, Gašperík J, Golais F (2002): A novel class of growth factors related to herpesviruses. Acta Vet. Brno 71, 29-36.

Mrázová V, Betáková T, Kúdelová $M$, Šupolíková M, Lachová V, Lapuníková B (2015): Murine gammaherpesvirus (MHV68) transforms the cells in vitro. Intervirology 58, 69-72. http://dx.doi.org/10.1159/000370071

Rajčáni J, Vojvodová A, Matis J, Kúdelová M, Dragúňová J, Krivjanská M, Zelník V (1996): The syn3 HSZP of Herpes simplex virus type 1 (HSV-1) is not pathogenic for mice and shows limited neural spread. Virus Res. 43, 33-44. http://dx.doi.org/10.1016/0168-1702(96)01318-4

Usherwood EJ, Stewart JP, Nash AA (1996): Characterization of tumor cell lines derived from murine gammaherpesvirus68 infected mice. J. Virol. 70, 6516-6518. 